\title{
Hyperbaric oxygen therapy promotes neurogenesis: where do we stand?
}

\author{
Jun $\mathrm{Mu}^{1,2}$, Paul R Krafft ${ }^{1}$ and John $\mathrm{H}$ Zhang ${ }^{1,2,3^{*}}$
}

\begin{abstract}
Neurogenesis in adults, initiated by injury to the central nervous system (CNS) presents an autologous repair mechanism. It has been suggested that hyperbaric oxygen therapy (HBOT) enhances neurogenesis which accordingly may improve functional outcome after CNS injury. In this present article we aim to review experimental as well as clinical studies on the subject of HBOT and neurogenesis. We demonstrate hypothetical mechanism of HBOT on cellular transcription factors including hypoxia-inducible factors (HIFs) and CAMP response element binding (CREB). We furthermore reveal the discrepancy between experimental findings and clinical trials in regards of HBOT. Further translational preclinical studies followed by improved clinical trials are needed to elucidate potential benefits of HBOT.
\end{abstract}

\section{Introduction}

Neurogenesis is defined as generation of neurons within the brain. In adults, neurogenesis occurs primarily in two brain regions: the subventricular (SVZ) and the subgranular zone (SGZ) of the hippocampal dentate gyrus (DG). Injury to the central nervous system (CNS) including trauma, cerebral ischemia and epileptic seizures have been reported to induce neurogenesis, and surviving cells may be functionally integrated into existing neural circuits [1]. Consequently, further endogenous promotion of neurogenesis may hold promise for restoration of cerebral functions after CNS injury.

Hyperbaric oxygen therapy (HBOT) refers to the medical use of oxygen at a level higher than atmospheric pressure. Initially, indicated for decompression illness it has been further applied to clinical conditions including crush injury, diabetic foot, skin grafts, thermal burns and to several neurological diseases [2]. Elevation of partial oxygen pressure in the body, leads to increased oxygen transport capacity of erythrocytes, facilitating peripheral regeneration processes (e.g. angiogenesis).

It has been suggested that HBOT exerts neuroprotective effects through a variety of mechanisms, including the activation of cellular transcription factors [3]. However, due to inconsistent results and few clinical trials,

\footnotetext{
* Correspondence: johnzhang3910@yahoo.com

'Department of Physiology, Loma Linda University School of Medicine,

11021 Campus Street, Loma Linda, CA 92354, USA

Full list of author information is available at the end of the article
}

HBOT for neurologic disorders has not yet been approved by the FDA. Further preclinical studies are needed to clarify the effect of HBOT on neurogenesis and to ensure a successful translation to clinical trials.

\section{Literature Review}

Publications were identified by PubMed/Medline and Web of Science, using the following keywords: neurogenesis, hyperbaric oxygen, ischemia, proliferation and BrdU. All publications, languages and subsets were explored. Results from previous studies were summarized into the following four categories: hypoxic-ischemic encephalopathy (HIE) (Table 1), vascular dementia (Table 2), permanent middle cerebral artery occlusion (MCAo) (Table 3) and human mesencephalic neural progenitor cells (hmNPCs) (Table 4).

Regarding HBOT, most preclinical studies were performed using a rat model of HIE. Wang et al. initiated 7 days of HBOT (2.0 ATA, 100\% oxygen, 1 hour daily) starting 3 hours after experimental HIE in rats. Results showed a significantly increased amount of BrdU+/nestin + cells in the SVZ with a peak at 7 days after HIE [4]. 21 days later, more BrdU+ $/ \beta$-tubulin+ cells were observed in the cortex of treated rats, suggesting that $\mathrm{HBOT}$ promotes the proliferation, differentiation and migration of newly generated cells [5].

Our preliminary data shows that HBOT decreases the infarct size with a significantly increased number of BrdU $(+)$ cells in the peri-infarct area 2 week after experimental 
Table 1 Hypoxic-ischemic encephalopathy (HIE)

\begin{tabular}{|c|c|c|c|c|c|c|c|c|}
\hline $\begin{array}{l}\text { Animal model/ } \\
\text { Cell line }\end{array}$ & HBO therapy & Method/Duration & Neurogenesis & $\begin{array}{l}\text { Infarct } \\
\text { size }\end{array}$ & $\begin{array}{l}\text { Neurobehavioral } \\
\text { testing }\end{array}$ & Mechanism & Institute & Reference \\
\hline HIE rats & $\begin{array}{l}\text { Within } 3 \mathrm{~h} 100 \%, 2 \text { ATA } \\
\qquad 1 \mathrm{~h} / \mathrm{d} \times 7\end{array}$ & $\begin{array}{l}\text { BrdU } 50 \mathrm{mg} / \mathrm{Kg} 2 \text { days } \\
\text { before sac Q8hX5T }\end{array}$ & SVZ $\uparrow$ Brdu+/nestin+ D3, D7, D14 after ischemia & / & / & Wnt-3 & $\begin{array}{l}\text { Central South } \\
\text { University, China }\end{array}$ & $\begin{array}{l}\text { Wang, et } \\
\text { al [4] }\end{array}$ \\
\hline HIE rats & $\begin{array}{l}\text { Within } 3 \mathrm{~h} 100 \%, 2 \text { ATA } \\
\qquad 1 \mathrm{~h} / \mathrm{d} \times 7\end{array}$ & $\begin{array}{l}\text { brdU } 50 \mathrm{mg} / \mathrm{Kg} 1 \text { days } \\
\text { after surgery Q12hX6D }\end{array}$ & SVZ $\uparrow$ Brdu+/nestin+ D3, D7, D14 after ischemia & / & / & MBP & $\begin{array}{l}\text { Central South } \\
\text { University, China }\end{array}$ & $\begin{array}{c}\text { Yang, et al } \\
\text { [11] }\end{array}$ \\
\hline HIE rats & $\begin{array}{l}\text { Within } 3 \text { h } 2 \text { ATA, 100\% } \\
\text { oxygen } 1 \mathrm{~h} / \mathrm{d} \times 7\end{array}$ & $\begin{array}{l}\text { brdU } 50 \mathrm{mg} / \mathrm{Kg} 1 \text { days } \\
\text { before HBO Q12hX6D }\end{array}$ & $\begin{array}{c}\uparrow D 7 \text { SVZ brdu+/DCX+ } \uparrow \text { D14 cortex brdu+/DCX } \\
+ \text { D28 cortex } \uparrow B r d U / G F A P / t u b u l i n\end{array}$ & / & / & / & $\begin{array}{l}\text { Central South } \\
\text { University, China }\end{array}$ & $\begin{array}{l}\text { Wang, et } \\
\text { al [5] }\end{array}$ \\
\hline $\begin{array}{l}\text { neural stem cell } \\
\text { from HIE rats }\end{array}$ & $\begin{array}{l}\text { Within } 2 \mathrm{~h} 2 \text { ATA, } 100 \% \\
\text { oxygen } \times 1 \mathrm{~h}\end{array}$ & / & $\begin{array}{c}\text { differentiate into } \begin{array}{c}\uparrow \text { neurons } \uparrow \text { oligodendrocytes } \\
\text { \astrocytes }\end{array}\end{array}$ & / & / & $\beta$-catenin, & $\begin{array}{l}\text { Central South } \\
\text { University, China }\end{array}$ & $\begin{array}{l}\text { Zhang, et } \\
\text { al [6] }\end{array}$ \\
\hline
\end{tabular}


Table 2 Vascular dementia

\begin{tabular}{|c|c|c|c|c|c|c|c|c|}
\hline $\begin{array}{l}\text { Animal model/ } \\
\text { Cell line }\end{array}$ & HBO therapy & $\begin{array}{l}\text { Method/ } \\
\text { Duration }\end{array}$ & Neurogenesis & $\begin{array}{l}\text { Infarct } \\
\text { size }\end{array}$ & $\begin{array}{l}\text { Neurobehavioral } \\
\text { testing }\end{array}$ & Mechanism & Institute & Reference \\
\hline $\begin{array}{l}\text { vascular dementia } \\
\text { (ligation of } \\
\text { Bilateral CCA) }\end{array}$ & $\begin{array}{l}100 \%, 2 \text { ATA, } \\
2 \mathrm{~h} / \mathrm{d} \times 10 \mathrm{~d}\end{array}$ & / & $\begin{array}{l}\text { piriform cortex } \\
\text { (Pir) } \\
\uparrow D C X+\text {, Nestin } \\
+\end{array}$ & / & $\begin{array}{l}\text { Shuttle box } \\
\text { testing }\end{array}$ & / & $\begin{array}{l}\text { Third } \\
\text { Military Medical } \\
\text { University }\end{array}$ & $\begin{array}{l}\text { Zhang et al } \\
\text { [12] }\end{array}$ \\
\hline
\end{tabular}

HIE. We treated operated animals with 1.5 ATA HBO, $100 \%$ oxygen once a day for 3 consecutive days. BrdU, dissolved in saline, was injected intraperitoneally $(50 \mathrm{mg} /$ kg) 24 hours after HIE, once a day for a total of 7 days.

Furthermore in vitro studies suggest that HBOT promotes neural stem cells differentiation into neurons or oligodendrocytes, while inhibiting those stem cells from differentiating into astrocytes [6,7]. HBOT also enhances the proliferation of other supporting cells, including glial cell line-derived neurotrophic nerve growth factor (GDNF) [8] and vascular endothelial growth factor (VEGF) positive cells [8] as well as epithelial cells [9] and human microvascular endothelial cells (HMEC-1) (Table 5) [10].

\section{Hypothetical mechanisms}

Numerous in vivo and in vitro studies confirm that HBOT induces neurogenesis [5-7,10-13] however, underlying mechanisms remain unknown. Activation of several signaling pathways and transcription factors have been suggested to play an important role in HBOT induced neurogenesis, including Wnt, hypoxia-inducible factors (HIFs) and cAMP response element-binding (CREB).

HIF-1 is a heterodimeric transcriptional complex composed of an inducible HIF- $1 \alpha$ subunit and a constitutive HIF-1 $\beta$ subunit. HIF- $1 \alpha$ is the principal mediator of cellular hypoxia adaptations [14]. Therefore activated by hypoxia, HIF-1 $\alpha$ causes the transcription of its regulated downstream genes, including erythropoietin (EPO) and VEGF which are known to promote neurogenesis [15]. However accumulation of HIF-1 $\alpha$ induces expression of p53 [16] and BNIP3 [17], leading to neuronal cell death. Thus neuroprotection may occur shortly after cerebral ischemia at balanced levels of HIF-1 $\alpha$. In the presence of oxygen and iron, HIF- $1 \alpha$ is rapidly degraded via the prolyl hydroxylase pathway. Javorina et al. discovered that HBOT exposure stabilizes HIF-1 $\alpha$ levels in hmNPCs and furthermore induces neurogenesis in vitro [7]. We suggest that HBOT prevents the accumulation of HIF-1 $\alpha$ and therefore exerts its neuroprotective effect (Figure 1).

Wnt signaling has been suggested to play an important role in the regulation of cell proliferation and differentiation during the stage of CNS development. Wnt3 is the starting protein of this pathway. Wang et al. confirmed increased level of Wnt-3 in HBOT rats 3 days after HIE induction, which was positively correlated with the proliferation of stem cells [4]. The authors suggest that cell proliferation via Wnt pathway is regulated through $\beta$-catenin. Furthermore, in vitro studies demonstrated that $\beta$-catenin siRNA decreases the amount of newly generated neurons by repressing the Neurogenin 1 (NGN1) gene, which can be reversed by HBOT [6]. It has been recently reported that HIF- $1 \alpha$ modulates Wnt/ $\beta$-catenin signaling in hypoxic embryonic stem cells (ESC) by enhancing $\beta$-catenin activation, and expression of the downstream effectors lymphocyte enhancer factor-1 (LEF-1) and T-cell factor-1 (TCF-1) [18].

It has been implicated that Hif- $1 \alpha$ deletion reduces Wnt/ $\beta$-catenin signaling in the SGZ, causing impaired Wnt-dependent processes, including neural stem cell proliferation, differentiation and neuronal maturation [18]. We conclude that activation of the Wnt pathway may occur via HBOT induced control of HIF-1 $\alpha$ (Figure 1).

CREB plays a well-documented role in neuronal plasticity and formation of long-term memory, mainly through up-regulation of its downstream genes including brain derived neurophic factor (BDNF), Bcl-2, c-fos and VGF. Activation of CREB increases neurogenesis in the DG after focal cerebral ischemia in rats, and protects against hypoxic brain injury [19]. Application of $100 \%$ oxygen increased CREB expression in striatum and hippocampus in a neonatal piglet model of intermittent apnea [20]. $\mathrm{HBO}$ preconditioning furthermore increased the ratio of $\mathrm{Bcl}-2$ and Bax expression in a MCAo/reperfusion model

Table 3 Permanent MCAo

\begin{tabular}{|c|c|c|c|c|c|c|c|c|}
\hline $\begin{array}{l}\text { Animal } \\
\text { model/Cell } \\
\text { line }\end{array}$ & HBO therapy & $\begin{array}{l}\text { Method/ } \\
\text { Duration }\end{array}$ & Neurogenesis & $\begin{array}{l}\text { Infarct } \\
\text { size }\end{array}$ & $\begin{array}{l}\text { Neurobehavioral } \\
\text { testing }\end{array}$ & Mechanism & Institute & Reference \\
\hline $\begin{array}{l}\text { Permanent } \\
\text { MCAo }\end{array}$ & $\begin{array}{l}\text { 100\%,2.5 ATA, } \\
1.5 \text { h } \\
\text { From } 15 \text { min, } 1.5 \text { h, } 3 \\
\text { h after MCAo }\end{array}$ & / & $\begin{array}{l}\text { D7 } \\
\uparrow G F A P+\end{array}$ & $\downarrow$ & garcia & / & $\begin{array}{l}\text { University of } \\
\text { Leipzig, Germany }\end{array}$ & $\begin{array}{l}\text { Gunther, } \\
\text { et al [13] }\end{array}$ \\
\hline
\end{tabular}


Table 4 Human mesencephalic neural progenitor cell

\begin{tabular}{|c|c|c|c|c|c|c|c|c|}
\hline $\begin{array}{l}\text { Animal model/ } \\
\text { Cell line }\end{array}$ & $\begin{array}{l}\text { HBO } \\
\text { therapy }\end{array}$ & $\begin{array}{l}\text { Method/ } \\
\text { Duration }\end{array}$ & Neurogenesis & $\begin{array}{l}\text { Infarct } \\
\text { size }\end{array}$ & $\begin{array}{l}\text { Neurobehavioral } \\
\text { testing }\end{array}$ & Mechanism & Institute & Reference \\
\hline hmNPCs & $\begin{array}{l}100 \%, 1.5 \\
\text { ATA } \\
1 \mathrm{~h} / \mathrm{d} \times 5 \mathrm{~d}\end{array}$ & Ki67 & $\begin{array}{l}\text { TMature neurons } \\
\text { (Tuji, NSE) } \\
\text {-GFAP }\end{array}$ & I & I & $\begin{array}{l}\text { HIF-a } \\
\text { Stabilizers }\end{array}$ & $\begin{array}{l}\text { University of Leipzig, } \\
\text { Germany }\end{array}$ & $\begin{array}{l}\text { Milosevic, } \\
\text { et al [7] }\end{array}$ \\
\hline
\end{tabular}

[21]. CREB activates its downstream genes when phosphorylated, while protein phosphatase-1 (PP1) catalyzes the dephosphorylation of CREB. PP $1 \gamma$ modulates the localization and/or activity of PP1. Suppressed in hypoxic conditions, PP1 leads to over-phosphorylation of CREB, followed by CREB ubiquitination and degradation by $26 \mathrm{~s}$ proteasome [22]. Although the exact role of CREB in HBOT induced neurogenesis is still not clear, we suggested that HBOT could reverse this process by reactivating PP $1 \gamma$ and by blocking the degradation of CREB (Figure 2).

\section{Clinical applications Stroke}

Neurons are highly energy demanding, a characteristic which makes them vulnerable to decreased cerebral blood supply during stroke. Experimental transient ischemia induces neurogenesis in the DG, with a peak between 7-10 days [23]. In confirmation to these results Shin et al. found the highest number of Brdu+ cells in the SVZ, subependymal zone, cortex and striatum 1 week after MCAo [24]. Thus endogenous neurogenesis after ischemic stroke occurs early and is short-lived.

HBOT appears to be a potent method of oxygen delivery [25]. It increases the oxygen partial pressure within the blood and enhances restoration of oxygen supply after ischemic stroke [26]. Previous studies provide evidence that HBOT promotes neurogenesis [4-6,11], reduces infarct size $[27,28]$ as well as hemorrhagic transformation [29] and improves neurological function, in animal models of ischemic stroke [28].
In contrast to these preclinical results no benefit of HBOT was found in stroke patients [30] and HBOT did not improve the clinical outcome in patients 6 months after acute stroke [31]. However, Singhal concluded that HBOT might extend the time window and increase the efficiency of FDA approved $r$-tPA thrombolysis after acute ischemic stroke [25].

Most clinical trials presented small sample sizes, undifferentiated stroke types, diverse time windows and varying application of HBOT. To bridge the gap between basic science and clinical studies, large scale, well designed, randomized controlled clinical trials are needed to examine the effects on HBOT in terms of acute sensorimotor and chronic cognitive function in patients.

\section{Traumatic brain injury (TBI)}

It has been established that injury-induced neurogenesis contributes greatly to post-injury recovery. After TBI, hippocampal progenitors are activated and result in increased amount of newly generated neurons within the DG [32]. Although there is no literature available on the HBOT induced neurogenesis in preclinical TBI models, HBOT has been applied to TBI patients. The use of HBOT for TBI remains controversial. McDonagh et al., concluded that there was insufficient evidence to establish the effectiveness of HBOT in the treatment of TBI [33]. Rockswold et al., on the other hand, found that HBOT might be potentially beneficial for severe TBI patients [34]. The safety of HBOT was also evaluated and it was pointed out that, if given at proper

Table 5 effect of HBOT on other type of cells

\begin{tabular}{|c|c|c|c|c|c|c|c|c|}
\hline $\begin{array}{l}\text { Animal model/ } \\
\text { Cell line }\end{array}$ & $\begin{array}{l}\text { HBO } \\
\text { therapy }\end{array}$ & $\begin{array}{l}\text { Method/ } \\
\text { Duration }\end{array}$ & Proliferation & $\begin{array}{l}\text { Infarct } \\
\text { size }\end{array}$ & $\begin{array}{l}\text { Neurobehavioral } \\
\text { testing }\end{array}$ & Mechanism & Institute & Reference \\
\hline $\begin{array}{l}\text { experimental } \\
\text { spinal cord } \\
\text { injury }\end{array}$ & $\begin{array}{l}\text { Right } \\
\text { after } \\
\text { injury } \\
100 \%, 2.5 \\
\text { ATA } \\
2 \text { h } \\
\end{array}$ & D7 & $\begin{array}{l}\uparrow G D N F(+) \text { cell } \\
\uparrow V E G F(+) \text { cell }\end{array}$ & $\downarrow T T C$ & $\begin{array}{l}\uparrow B B B \text { locomotor } \\
\text { scale }\end{array}$ & $\begin{array}{l}\text { \myeloperoxidase (MPO), tumor } \\
\text { necrosis factor-a (TNFa) and } \\
\text { interleukin-1b (IL-1b) }\end{array}$ & $\begin{array}{l}\text { Taipei Medical } \\
\text { University }\end{array}$ & $\begin{array}{l}\text { Tai, et al } \\
{[8]}\end{array}$ \\
\hline Normal rats & $\begin{array}{l}60 \%, 1 \\
\text { ATA } \\
3 \text { days }\end{array}$ & $\begin{array}{l}\text { Brdu } \\
\text { Single } \\
\text { injection }\end{array}$ & $\begin{array}{l}\text { germinative } \\
\text { zone } \\
\uparrow \text { Epithelial } \\
\text { Cells }\end{array}$ & / & / & Oxidative stress? & $\begin{array}{l}\text { Washington } \\
\text { University }\end{array}$ & $\begin{array}{l}\text { Shui et al } \\
{[9]}\end{array}$ \\
\hline HMEC-1 & $\begin{array}{l}100 \%, 2.4 \\
\text { ATA } \\
1 \mathrm{~h}\end{array}$ & / & $\begin{array}{l}\uparrow H M E C-1 \\
\text { proliferation }\end{array}$ & / & / & $\begin{array}{l}\text { antioxidant, cytoprotective } \\
\text { genes upregulation }\end{array}$ & $\begin{array}{l}\text { University of } \\
\text { Connecticut, } \\
\text { USA }\end{array}$ & $\begin{array}{l}\text { Godman } \\
\text { et al [10] }\end{array}$ \\
\hline
\end{tabular}




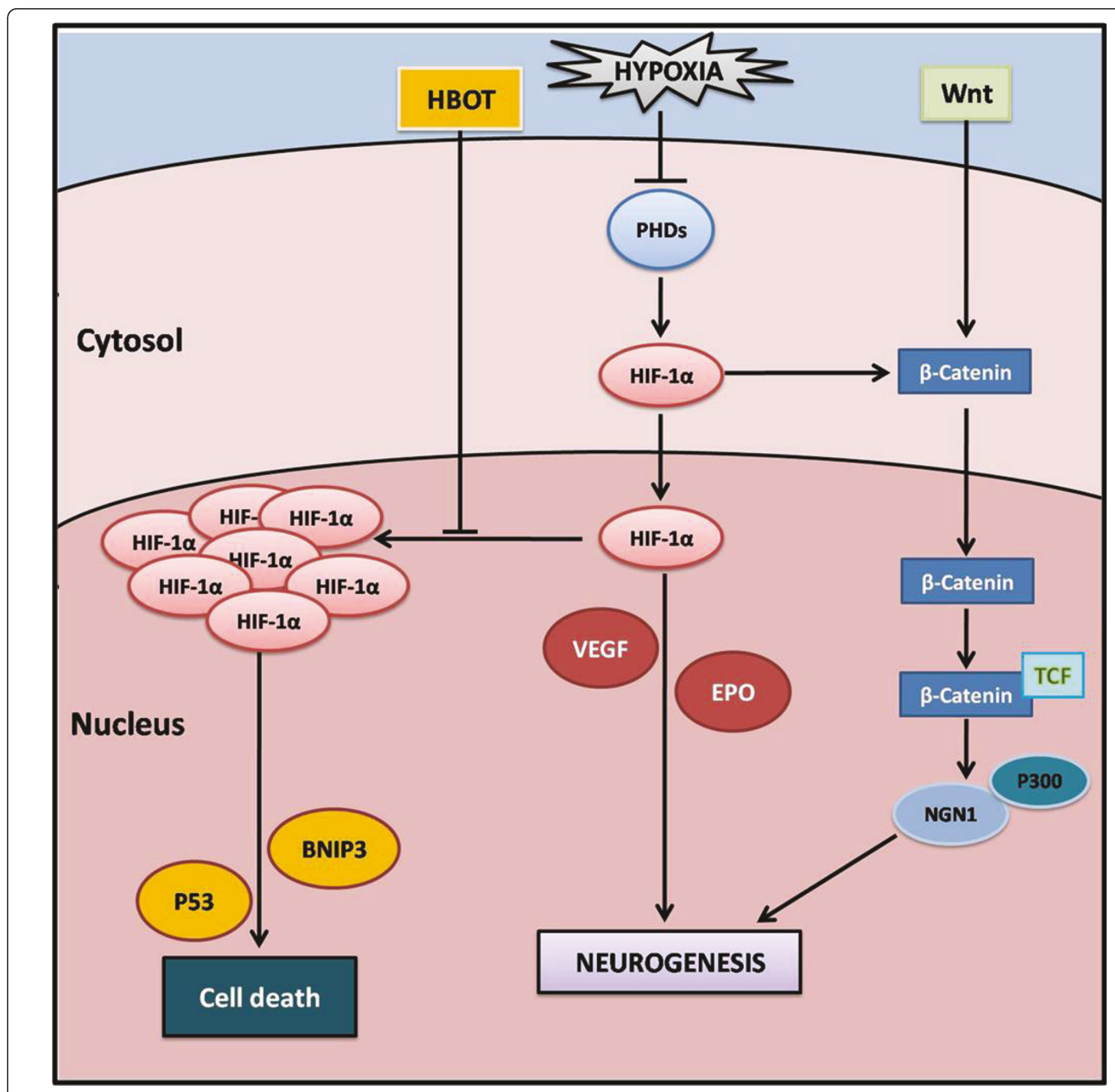

Figure 1 Potential mechanisms of HBOT and HIF-1 $\alpha$. In hypoxia, HIF-1 $\alpha$ activates EPO and VEGF to promote neurogenesis. The accumulation of HIF-1 $\alpha$ further induces the expression of p53 protein and BNIP3, leading to cell death. HBOT stabilizes HIF-1 $\alpha$, preventing it from overexpression and further, activates the Wnt pathway. Abbreviation: PHDs, prolyl hydroxylase; HIF-1 $\alpha$, hypoxia-inducible factor 1 $\alpha$; EPO, e rythropoietin; VEGF, vascular endothelial growth factor; NGN1, Neurogenin1; TCF, T-cell factor.

paradigms, like 1.5 ATA for 60 minutes, HBOT will not cause oxygen toxicity [34]. In a review of available treatments for acquired brain injury (ABI), including TBI, HBOT was suggested with strong level of evidence among non-pharmacological interventions of ABI. Furthermore, HBOT positively improved mortality with level 1 evidence [35]. Laboratory experiments on HBOT induced neurogenesis are needed to investigate the efficiency of HBOT on TBI.

\section{Autism}

Autism is a neuro-developmental disorder associated with hypoperfusion to several areas of the brain, defects of neurogenesis and neuronal migration [36]. The first multicenter, randomized, double-blind, controlled trial in 2009 found that 40-hour HBOT of $24 \%$ oxygen at 1.3 ATM produced significant improvement in children's overall functioning, receptive language, social interaction, eye contact, and sensory/cognitive awareness compared 


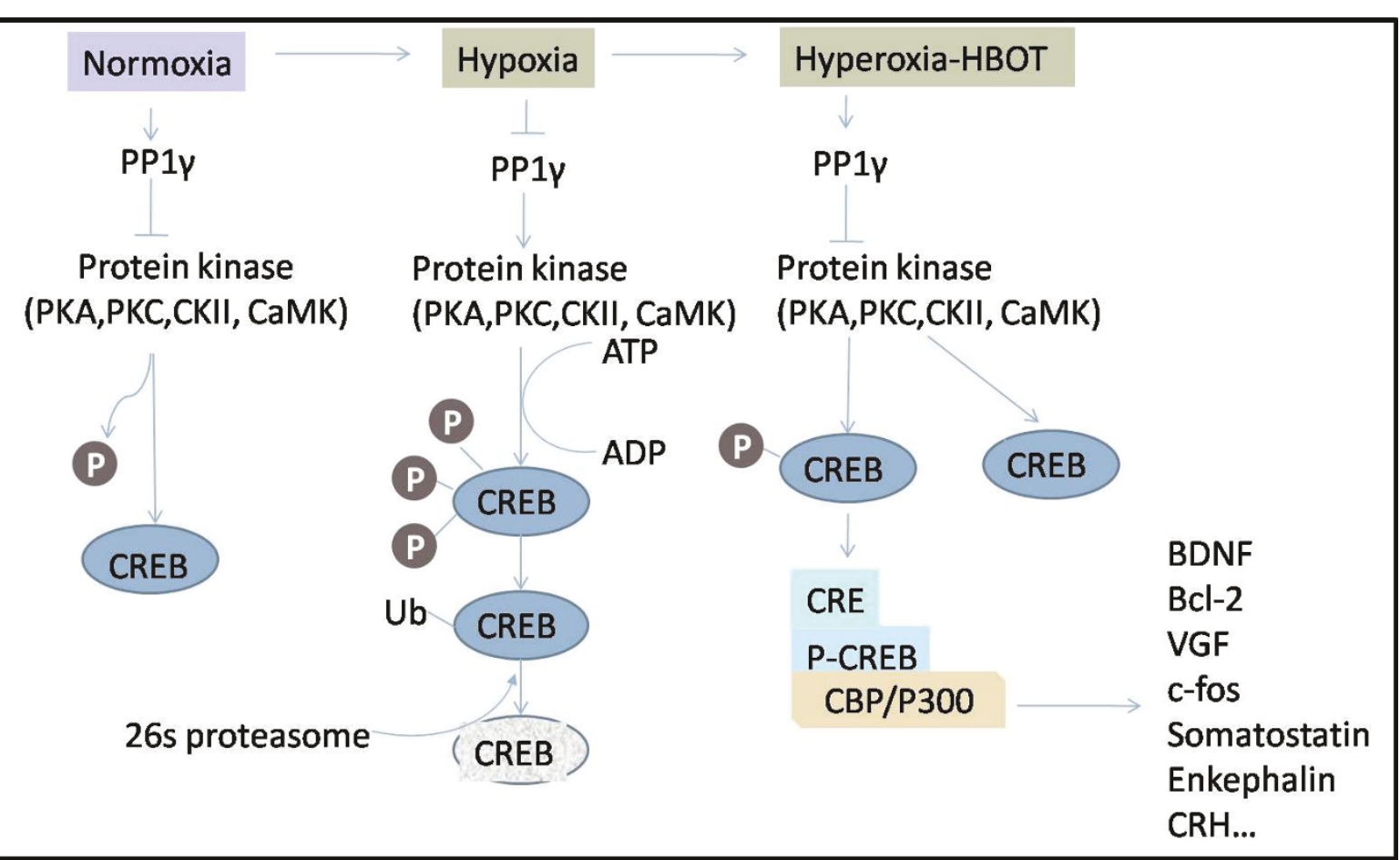

Figure 2 Potential mechanisms of HBOT associated CREB activation and degradation: CREB activates its downstream genes when phosphorylated, while PP1 catalyzes the dephosphorylation of CREB. PP1 $\gamma$ is the core subunit of PP1. In hypoxia, PP1 $\gamma$ is repressed, leading to over-phosphorylation of CREB, followed by CREB ubiquitination and degradation by $26 \mathrm{~s}$ proteasome. HBOT may reverse this process by reactivating PP1 $\gamma$ and blocking CREB degradation. Thus, phosphorylated CREB activates the downstream genes (BDNF, BCl-2, VGF, et al.) to promote neurogenesis. Abbreviation: PP1 $\gamma$, protein phosphatase-1; CREB, CAMP response element-binding; Ub, ubiquitin; CRE, CAMP response elements; CBP, CREB binding protein.

to those received slightly pressurized room air [37]. Another study in 2010 on 16 autism patients, adopting a similar treatment paradigm, showed no effect on a wide array of behavioral evaluations [38]. Basic research is needed regarding neuroprotective effects of HBOT and neurogenesis.

\section{Special concerns}

\section{HBOT and malignancy}

It has been previously suggested that neurogenesis occurs within an angiogenic niche, where neurogenesis is closely associated with vascular recruitment and subsequent remodeling [39]. Therefore HBOT may also stimulate angiogenesis by enhancing the proliferation of fibroblasts, epithelial cells and blood vessels [40].

Concerns have been raised whether HBOT promotes the proliferation of cancer cells. To date, there is little evidence that HBOT causes malignant growth or metastasis. A history of malignancy should therefore not be considered as a contraindication for HBOT [40].

\section{HBOT and oxidative stress}

HBOT enhances the production of reactive oxygen species (ROS) and causes oxidative stress in body tissues
[10]. Excessive accumulation of oxidative stress may contribute to neurodegenerative processes and cell death in the brain, as seen in diseases like Alzheimer's disease (AD) and Parkinson's disease (PD) [41]. Since HBOT-induced oxidative stress is directly proportional to both exposure pressure and duration, the benefits of HBOT, may outweigh the side effects due to the phenomenon of hormesis. Hormesis is a process that results in a functional improvement of cellular stress resistance, survival, and longevity in response to sub-lethal levels of stress. We suggest that this process might be beneficial in the treatment of oxidative stress associated neurodegenerative diseases like $\mathrm{AD}$ and $\mathrm{PD}$.

\section{Conclusions and future directions}

Abounding evidence has shown that HBOT promotes neurogenesis. Future investigations need to be extended to models of neurological diseases, including subarachnoid hemorrhage $(\mathrm{SAH})$, cerebral hemorrhage, $\mathrm{AD}, \mathrm{PD}$, surgical brain injury (SBI) and autism for cell proliferation, survival and differentiation. Furthermore, studies need to be conducted to explore whether HBOT induced neurogenesis leads to a functional improvement followed by large scale, strictly controlled clinical trials 
to establish HBOT as a prevention and/or treatment modality for neurological diseases.

\section{Acknowledgements}

We thank Robert P. Ostrowski for his valuable contributions. This work is supported by a grant from National Nature Science Foundation of China (No.30570657) and 973 project (2009CB918300).

\section{Author details}

'Department of Physiology, Loma Linda University School of Medicine, 11021 Campus Street, Loma Linda, CA 92354, USA. ${ }^{2}$ Department of Neurology, The First Affiliated Hospital of Chongqing Medical University, 1 Yi Xue Yuan Road, Chongqing 400016, China. ${ }^{3}$ Department of Neurology, Loma Linda University School of Medicine, 11234 Anderson Street, Loma Linda, CA 92354, USA.

\section{Conflicts of Interests /Disclosures}

The authors declare that they have no competing interests.

Received: 6 April 2011 Accepted: 27 June 2011 Published: 27 June 2011

\section{References}

1. Alvarez-Buylla A, Lim DA: For the long run: maintaining germinal niches in the adult brain. Neuron 2004, 41(5):683-6.

2. Mychaskiw G: Hyperbaric oxygen therapy and neurologic disease: the time has come. Undersea Hyperb Med 2010, 37(2):xi-xiii.

3. Matchett GA, Martin RD, Zhang JH: Hyperbaric oxygen therapy and cerebral ischemia: neuroprotective mechanisms. Neurol Res 2009, 31(2):114-21

4. Wang $X \mathrm{~L}$, et al: Proliferation of neural stem cells correlates with Wnt-3 protein in hypoxic-ischemic neonate rats after hyperbaric oxygen therapy. Neuroreport 2007, 18(16):1753-6.

5. Wang $\mathrm{XL}$, et al: [Hyperbaric oxygen promotes the migration and differentiation of endogenous neural stem cells in neonatal rats with hypoxic-ischemic brain damage]. Zhongguo Dang Dai Er Ke Za Zhi 2009, 11(9):749-52

6. Zhang $X Y$, et al: The role of beta-catenin signaling pathway on proliferation of rats neural stem cells after hyperbaric oxygen therapy in vitro. Cell Mol Neurobiol 2011, 31(1):101-9.

7. Milosevic J, et al: Non-hypoxic stabilization of hypoxia-inducible factor alpha (HIF-alpha): relevance in neural progenitor/stem cells. Neurotox Res 2009, 15(4):367-80

8. Tai PA, et al: Attenuating experimental spinal cord injury by hyperbaric oxygen: stimulating production of vasculoendothelial and glial cell linederived neurotrophic growth factors and interleukin-10. J Neurotrauma 2010, 27(6):1121-7.

9. Shui YB, Beebe DC: Age-dependent control of lens growth by hypoxia. Invest Ophthalmol Vis Sci 2008, 49(3):1023-9.

10. Godman CA, et al: Hyperbaric oxygen treatment induces antioxidant gene expression. Ann N Y Acad Sci 2010, 1197:178-83.

11. Yang YJ, et al: Hyperbaric oxygen induces endogenous neural stem cells to proliferate and differentiate in hypoxic-ischemic brain damage in neonatal rats. Undersea Hyperb Med 2008, 35(2):113-29.

12. Zhang $T$, et al: Hyperbaric oxygen therapy improves neurogenesis and brain blood supply in piriform cortex in rats with vascular dementia. Brain Inj 2010, 24(11):1350-7.

13. Gunther A, et al: Reduced infarct volume and differential effects on glial cell activation after hyperbaric oxygen treatment in rat permanent focal cerebral ischaemia. Eur J Neurosci 2005, 21(11):3189-94.

14. Chen W, et al: HIF-1alpha inhibition ameliorates neonatal brain injury in a rat pup hypoxic-ischemic model. Neurobiol Dis 2008, 31(3):433-41.

15. Lanfranconi $\mathrm{S}$, et al: Growth factors in ischemic stroke. J Cell Mol Med 2009.

16. Halterman MW, Federoff HJ: HIF-1alpha and p53 promote hypoxiainduced delayed neuronal death in models of CNS ischemia. Exp Neurol 1999, 159(1):65-72.

17. Mellor HR, Harris AL: The role of the hypoxia-inducible $\mathrm{BH} 3$-only proteins BNIP3 and BNIP3L in cancer. Cancer Metastasis Rev 2007, 26(3-4):553-66.
18. Mazumdar J, et al: $\mathrm{O} 2$ regulates stem cells through $\mathrm{Wnt} /$ beta-catenin signalling. Nat Cell Biol 2010, 12(10):1007-13.

19. Zhu DY, et al: Activation of cAMP-response-element-binding protein (CREB) after focal cerebral ischemia stimulates neurogenesis in the adult dentate gyrus. Proc Natl Acad Sci USA 2004, 101(25):9453-7.

20. Mendoza-Paredes A, et al: Resuscitation with $100 \%$, compared with $21 \%$, oxygen following brief, repeated periods of apnea can protect vulnerable neonatal brain regions from apoptotic injury. Resuscitation 2008, 76(2):261-70

21. Li JS, et al: Hyperbaric oxygen preconditioning reduces ischemiareperfusion injury by inhibition of apoptosis via mitochondrial pathway in rat brain. Neuroscience 2009, 159(4):1309-15.

22. Taylor $C T$, et al: Phosphorylation-dependent targeting of cAMP response element binding protein to the ubiquitin/proteasome pathway in hypoxia. Proc Natl Acad Sci USA 2000, 97(22):12091-6.

23. Lichtenwalner RJ, Parent JM: Adult neurogenesis and the ischemic forebrain. I Cereb Blood Flow Metab 2006, 26(1):1-20

24. Shin $\mathrm{HY}$, et al: Endogenous neurogenesis and neovascularization in the neocortex of the rat after focal cerebral ischemia. J Neurosci Res 2008, 86(2):356-67.

25. Singhal $A B$ : A review of oxygen therapy in ischemic stroke. Neurol Res 2007, 29(2):173-83.

26. Poli S, Veltkamp R: Oxygen therapy in acute ischemic stroke-experimental efficacy and molecular mechanisms. Curr Mol Med 2009, 9(2):227-41.

27. Yin $D$, et al: Inhibition of apoptosis by hyperbaric oxygen in a rat focal cerebral ischemic model. J Cereb Blood Flow Metab 2003, 23(7):855-64.

28. Yin D, Zhang JH: Delayed and multiple hyperbaric oxygen treatments expand therapeutic window in rat focal cerebral ischemic model. Neurocrit Care 2005, 2(2):206-11.

29. Sun $L$, et al: Oxygen therapy reduces secondary hemorrhage after thrombolysis in thromboembolic cerebral ischemia. J Cereb Blood Flow Metab 2010, 30(9):1651-60

30. Carson S, et al: Hyperbaric oxygen therapy for stroke: a systematic review of the evidence. Clin Rehabil 2005, 19(8):819-33.

31. Bennett MH, et al: Hyperbaric oxygen therapy for acute ischaemic stroke. Cochrane Database Syst Rev 2005, 3: CD004954.

32. Kernie SG, Parent JM: Forebrain neurogenesis after focal Ischemic and traumatic brain injury. Neurobiol Dis 2010, 37(2):267-74.

33. McDonagh $M$, et al: Hyperbaric oxygen therapy for traumatic brain injury: a systematic review of the evidence. Arch Phys Med Rehabil 2004, 85(7):1198-204.

34. Rockswold SB, Rockswold GL, Defillo A: Hyperbaric oxygen in traumatic brain injury. Neurol Res 2007, 29(2):162-72

35. Meyer $\mathrm{MJ}$, et al: Acute management of acquired brain injury part I: an evidence-based review of non-pharmacological interventions. Brain Inj 2010, 24(5):694-705.

36. Wegiel J, et al: The neuropathology of autism: defects of neurogenesis and neuronal migration, and dysplastic changes. Acta Neuropathol 2010 119(6):755-70

37. Rossignol DA, et al: Hyperbaric treatment for children with autism: a multicenter, randomized, double-blind, controlled trial. BMC Pediatr 2009, 9:21.

38. Jepson B, et al: Controlled Evaluation of the Effects of Hyperbaric Oxygen Therapy on the Behavior of 16 Children with Autism Spectrum Disorders. J Autism Dev Disord 2011, 41(5):575-88.

39. Palmer TD, Willhoite AR, Gage FH: Vascular niche for adult hippocampal neurogenesis. J Comp Neurol 2000, 425(4):479-94.

40. Feldmeier J, et al: Hyperbaric oxygen: does it promote growth or recurrence of malignancy? Undersea Hyperb Med 2003, 30(1):1-18

41. Taupin P: A dual activity of ROS and oxidative stress on adult neurogenesis and Alzheimer's disease. Cent Nerv Syst Agents Med Chem 2010, 10(1):16-21.

doi:10.1186/2045-9912-1-14

Cite this article as: Mu et al:: Hyperbaric oxygen therapy promotes neurogenesis: where do we stand? Medical Gas Research 2011 1:14 